https://helda.helsinki.fi

\title{
Mourning becomes the nation : television coverage of the murder of Pim Fortuyn
}

\section{Pantti, Mervi}

2005

Pantti , M \& Wieten , J 2005 , ' Mourning becomes the nation : television coverage of the murder of Pim Fortuyn ' , Journalism studies, vol. 6 , no. 3 , pp. 301-313 .

http://hdl.handle.net/10138/230081

publishedVersion

Downloaded from Helda, University of Helsinki institutional repository.

This is an electronic reprint of the original article.

This reprint may differ from the original in pagination and typographic detail.

Please cite the original version. 


\title{
Mourning Becomes the Nation: television coverage of the murder of Pim Fortuyn
}

\author{
MERVI PANTTI and JAN WIETEN University of Amsterdam, Netherlands
}

\begin{abstract}
This article enters the debate on media events by analysing Dutch television news reporting of the death of controversial right-wing politician Pim Fortuyn. It aims to demonstrate how the coverage of the murder, in particular the representation of emotions, was implicated in the construction of a national, multicultural consensus. A nationwide bereaved community was created by focusing on expressions of mourning, and converting emotions like anger and hate into a unifying and less destructive depiction of grief.
\end{abstract}

Key Words: Media Events, Feeling Community, News, Emotion, Mourning

\section{Introduction}

In recent years television viewers have been witnesses to many previously "unimaginable" emotional events. In the Netherlands, approximately 20,000 outraged citizens gathered in central Amsterdam in the beginning of November 2004 to pay homage to murdered filmmaker and journalist Theo van Gogh by making seven minutes of "ear-deafening noise", to support freedom of speech. ${ }^{1}$ Just a few weeks before some 40,000 weeping fans participated in the memorial service for popular singer André Hazes at the Amsterdam Arena stadium, and more than five million people, almost one-third of the Dutch population, watched the event live on television. Few people seemed surprised that the expressions of grief sparked by his death also featured as the main item on the television news, even on public TV.

It is not breaking news that news journalism is invaded by both individual and collective displays of emotion (e.g. Aldridge, 2001; Kitch, 2000; Walter, 1991; Walter et al., 1995). Coverage of any culturally proximate tragedy will now include depictions of public mourning, "vox pops" telling about ordinary people's feelings, and expert comments on how to deal with the trauma. That the interest in public outpourings of emotion and the formation of unprompted feeling communities is not confined within the national borders becomes clear, for instance, in a Dutch newspaper story (de Volkskrant, 7 September 2004) about a mass demonstration in Italy following the tragic school siege in Beslan, Russia: "Already on Saturday a spontaneous sms-chain reaction was set off throughout Italy calling for people to put candles in their windows."

As several scholars have noted, there seems to be a remarkably uniform frame in covering extraordinary tragic events. Typically they are represented as integrative events, moments of national consensus and unity born out of mourning together (e.g. Cloud, 1998; Kitch, 2000, 2003; Linenthal, 2001; Örnebring, 2004; Pantti, 2005; Walter et al., 1995). When a disaster, such as a political murder, occurs such communion is achieved through news media, which can create and convey a feeling of temporary national consensus, "a nationwide bereaved community" (see Linenthal, 2001, p. 111), in an otherwise fragmented society. Media's ritual role of bringing people together is most often studied in the context of media events. In their influential study, Dayan and Katz (1992, pp. 196-7) see media events, defined as dominating televised occasions based on interruption and withdrawal from routine broadcast schedules, as affirmation of social bonds and as moments 
when the dominant societal values are most actively maintained. Our work enters into this debate on media events by asking how the representation of public displays of emotion in the news coverage of the assassination and funeral of a Dutch right-wing populist politician Pim Fortuyn was implicated in the mechanism of constructing, to reformulate Benedict Anderson's (1991) well-circulated concept, an imagined feeling community that brings people temporarily together in otherwise fragmented society.

In the theory of media events, extraordinary events feature as a ground that allows the spirit of communitas to overcome the divisions (see Daniel and Katz, 1992). Extraordinary, dramatic events offer a place where the media can position itself as the protector of societal values and cultural identities. The ideological nature of media events has received some critical attention recently (e.g. Couldry, 2003; Örnebring, 2004). The media event brings to the surface the values and assumptions that are most central to a particular culture, but it may also have the effect of silencing other values and alternative perspectives. Echoing Couldry's (2003) view that media events are as much constructions as expressions of togetherness we argue that news reproduces emotional expression with ideological consequences. Even if media events normally may be expected to render support to society's value system, that is not always or automatically the case. The outcome may be in opposition of it, even intensify social conflict, or, as our study suggests, remain unpredictable and uncertain. Fortuyn's case is fascinating because of his political message that went against Dutch society's celebrated values of tolerance and openness. In contrast to, for instance, murdered Swedish politicians Olof Palme and Anna Lindh who were constructed in the media as symbols of Nordic identity and values (Pantti, 2005), it is more difficult to imagine how the murder of a controversial figure like Fortuyn could be used to create consensus. Fortuyn's death, like his life, was potentially divisive, but in television news coverage there was little room for the voices of discontent and internal controversies.

We analysed the main television news broadcasts of Dutch public broadcaster NOS and commercial broadcaster (RTL4) on the days following the murder of Fortuyn, from the day of the murder (6 May 2002) until the day of the funeral (10 May 2002). NOS Journaal (public) and RTL Nieuws (commercial) are the main evening news programmes on Dutch television. The NOS Journaal averages the bigger audience of the two. In the week of the murder the audiences for both NOS and RTL4 news, but especially NOS Journaal, were larger than usual. SBS, the other main commercial broadcaster next to RTL, has been searching for a competitive evening news formula. Its evening news, broadcast under different names since 1997 (Actienieuws, SBS6 Nieuws, Het Nieuws, and Stem van Nederland) and broadcast at different times, reached only a minor fraction of the television audience in 2002. ${ }^{2}$ On 6 and 7 May, Fortuyn's death was the only item in both NOS and RTL4 news. The main evening news bulletins of NOS at 8 o'clock and RTL4 at 7.30 on the night of the murder were extended programmes and part of continuous, largely live news broadcasts. On some of the following days and again on the day of the funeral the news bulletins were extended beyond their normal 25 (NOS) or 20 minutes (RTL4) duration. The funeral service and the funeral of Pim Fortuyn on 10 March 2002 were broadcast live both on NOS and RTL4.

\section{Extraordinary Death of Extraordinary Politician}

Fortuyn was shot on 6 May 2002 when he left a public radio studio in a Hilversum media park, where he had been interviewed. The murderer who turned out to be a white environment and animal rights activist was arrested only a little later. Because of his controversial opinions Pim Fortuyn was not one who would have solicited massive mourning if he had died a natural death. His assassination, however, was followed by a vast demonstration of public grief, with floral tributes, candles, notes, silent marches, and mourners lining up to view his body lying in state in a cathedral in Rotterdam.

Fortuyn had had an erratic political career; his political sympathies had moved from the Maoist left, via the Labour Party to the right-leaning 
Dutch Liberals. In 2001 a recently formed combination of local and regional parties, called Leefbaar Nederland (Liveable Netherlands) asked him to head their list for the 2002 national election. At first glance dandyish Fortuyn, with his ostentatious display of his homosexuality, might have seemed an unlikely choice to win an election, but his provocative way of raising issues that had been considered highly incorrect in the official compromise-seeking political climate of the Netherlands brought him a considerable degree of public attention and popularity. Television, normally focusing on the main parties represented in parliament, soon started to pay critical attention to him. Leefbaar Nederland scored ever higher in the polls, but when Fortuyn suggested in a newspaper interview that the anti-discrimination first article of the Dutch constitution could be abolished, the leadership of the Leefbaar Nederland party made him resign. After this he formed his own group, the List Pim Fortuyn.

Although Fortuyn accused the newspaper of having rigged the interview, his anti-immigration and anti-Muslim rhetoric, and antimulti-ethnic society standpoints increased his popularity but also the suspicion of his aims among other party leaders and in the media. Fortuyn claimed that the Netherlands was "full up", and he wanted a stop to further immigration, particularly from the Muslim world. He criticized Islamic culture as "backward culture" and condemned the failure of Muslims to assimilate with Dutch culture. However, Fortuyn cannot be characterized simply as another far-right politician, such as Jean-Marie Le Pen in France or Jörg Haider in Austria. He combined, for instance, an anti-immigration position with liberal views on drugs and same-sex marriage, and even propagated a general amnesty for the thousands of illegal immigrants living in the Netherlands. These views obviously did not have an adverse effect on his popularity. On the other hand, Fortuyn's ideas about environment protection and animal rights (he was in favour of mitigating restrictive regulation of the fur industry), which may have provided the motive for his murder, had received little media attention and had hardly been discussed during the election campaign.
The other party leaders, especially those of the ruling social-democratic-liberal coalition, who he held responsible for the "ruinous state" of the country, had great difficulty in finding answers to his provocations. He triumphed in most television debates with leaders of other political parties, such as one organized by commercial broadcaster RTL in the setting of an entertainment show, in which the established politicians felt conspicuously ill at ease. On public TV Fortuyn also won an easy victory over other politicians, when they were outwitted by him and proved to be bad losers on municipal-election day 2002. Fortuyn's list had won an astonishing share of the vote during these elections and had carried one major city, Rotterdam, where the long-ruling Labour Party was swept away. At that time the polls already predicted that he would repeat this success at the 15 May general elections and might collect nearly 20 per cent of votes. Eventually, Pim Fortuyn's List ended up as the second largest party in parliament, behind the ChristianDemocrats. Especially Labour and the Liberals, the main parties in Wim Kok's coalition government, suffered dramatic losses.

\section{Constructing Feeling Communities}

On the night of the murder the emotional atmosphere in the Netherlands was one of high tension and anxiety. The political centre, The Hague, became a scene of riots, as protesters burned cars and smashed windows next to the government they blamed for his murder. However, the response cannot be fully understood as spur-of-the-moment reaction to an extraordinary event: it should be seen within the context of a more lasting emotional climate that is related to underlying social-political structures and to the emotional relationships between members of the society (see De Rivera, 1992). One could speak of a climate of dissatisfaction (voiced by Fortuyn and heightened by his murder, as recent ethnic tension in the Netherlands suggests) occurring when the people cannot foresee what will happen either politically or economically in the near future, and there is a distrust between different (ethnic) groups. Only a few weeks before Fortuyn's 
assassination, the Dutch government had felt obliged to resign after the publication of a highly critical report of its conduct during the civil war in former Yugoslavia and the Srebrenica massacre. Thus the emotional reactions of the Dutch public to the death of Fortuyn may be related to a popular mistrust of authority and a deeper sense of threat to both national and personal security.

The death of Princess Diana can be seen as a key example of how difficult it is to separate what the public reaction really is from the public reaction constructed by the media. There are several studies (e.g. Kitzinger, 1998; Turnock, 2000; Walter, 1999) that demonstrate that despite the media rhetoric of a people "united in grief", there were also many people who were not personally affected by the death of the princess. These studies make obvious that the rhetoric of the "whole nation is mourning" may stand in sharp contrast with actual emotions and behaviour of the majority of the people. Less observed but similarly important is the question about what is the emotion or emotions expressed in these extraordinary events? In the case of the death of public figures, or tragedies like 9/11 and the Madrid train bombings, the public expressions are usually classified under the heading of grief. One reason for this could be that grief is perceived as "safe", unifying emotion, whereas the emotions of anger and hate are aggressive and divisive. Deborah Lupton (1998, p. 171; also Furedi, 2004; Mestrovich, 1997) argues, that while valuing the open expression of emotions, contemporary Western culture is also wary of uncontrolled emotions, especially negative feelings, such as anger, hate and rage, that are viewed as personally and socially destructive.

Emotions, including outbursts of popular dissatisfaction, have always been part of public life. As many political scientists and sociologist have recently rediscovered, emotions lie beneath political action and mobilization (e.g. Berezin, 2002; Goodwin et al., 2001; Marcus, 2002). Collective emotional experiences can reinforce the social order and bind people into a moral community, but they can also stimulate social change and revolt (Shilling, 2002). Due to this "power of feeling" ruling elites have never been indifferent to the emotional life of the public and governments have always taken seriously the task of managing the public mood (Furedi, 2004). On the other hand, as Furedi (2004, p. 49) claims, one of the characteristics of the Western "therapy culture" is that emotions have been made safe, depoliticized. Therefore, according to him, the public display of emotions is less likely to be perceived as a source of instability by the traditional elite. Against this claim, the statement of Prime Minister Wim Kok on the day of the murder (NOS Journaal; RTL Nieuws, 6 May) certainly suggests that the Dutch government was not unconcerned about the possibility that the murder might create undesirable emotional responses and turn emotional crowds into mobs:

This is deeply tragic for his next of kin. Deeply tragic for our country and our democracy ... In The Netherlands! In a tolerant country with respect for each other's opinions ... These are my personal feelings. I feel shattered. I felt an urgent need to tell you this. Let's in God's name keep calm! At a time when one is inclined to be quite furious, quite angry. Calm is perhaps the best service now that we can render, in dignity, to the rule of law and democracy and to the memory of Pim Fortuyn.

The media play an important role in managing emotions and repairing social life during major tragedies. Media can, for instance, actively contribute to turning a climate of anxiety and fear into one of restored morale and unification. Kitch (2003) has described how the American news-magazine coverage of the events of September 11 constructed a progressive narrative in which the negative feeling of fear was transformed into the positive feelings of courage and patriotic pride. In the case of Fortuyn, the question was perhaps more one of trying to convert the divisive and destructive sentiments of anger and hate into a unifying and more passive feeling of grief, thereby stripping public emotion of its "revolutionary" potential. According to Hans Laroes, the managing editor of the public NOS Journaal, the design how to manage the public mood and outbursts of emotions came from above: 
The cabinet's reaction was: we must make this a national event, just to be able to keep it in hand more or less. And to some extent this is also how we felt... The funeral got the character of a national event, while it was not, of course. For it was the mourning of one group, of people who were opposed to the other people who walked along with them and who were opposed to us who filmed it. $^{3}$

That anxiety and controversy existed in the Netherlands became obvious firstly through an unexpected level of support for Fortuyn after his murder. What public television news (NOS Journaal, 9 May) was worried about happened in the end: "people voted with their emotions". Another blow, even if symbolic, to the Dutch cultural and political elite was that anti-immigration and anti-Islam Fortuyn was declared as "the greatest Dutchman of all times" in the television contest of the same name (NOS, 16 November 2004), coming ahead of "respectable" figures like William of Orange, Rembrandt or Vincent Van Gogh. In the wake of the killing of Theo van Gogh political dissatisfaction reached another, and without doubt more frightening level, as the ethnic and religious conflicts worsened to the point of open violence, such as the burning of Islamic schools.

Certainly, there is nothing new about the creation of community or consensus in broadcasting. From the beginning broadcasting has been organized within the territory of a state with the explicit aim to serve the nation, and, what is important in our discussion, also to help construct a sense of national unity (Morley and Robins, 1995, p. 10). Serving the whole nation, implied an educative and civilizing mission, one of making the people aware of national identity, of belonging together, of sharing a language and a culture, of community (Cardiff and Scannell, 1987; Harrison, 2000; Syvertsen, 1992). Even where broadcasting was not organized as a public corporation, as in the Netherlands, there was something comparable to a public service remit, in its provision of an anchor for national cultural identification. Although in the multiethnic and multi-cultural European societies of today the public service remit is defined with less weight on the nation (Brants and de Bens, 2000), there are certain programme types that explicitly emphasize the idea of national com- munity and serve as venues for social cohesion. Broadcasting the ceremonies and rituals of the nation - royal weddings and funerals, Independence Day celebrations and the opening of parliament - has remained a priority and prerogative of national broadcasters. It is not so much their informative value that produces the necessity for television to provide them, but the fact that such events allow shared beliefs to be invoked in order to bring people together (cf. Carey, 1989), as well as to intensify emotional identification with the polity (Berezin, 2002). Benedict Anderson (1991) highlights the importance of mediated communication for national identity: an "imaginary" community means that national identities must be constructed and reproduced through discursive practices instead of actual experiences. It has been claimed that television in particular has become essential in creating post-modern social unity (van Zoonen, 2002). Besides the emphasis of difference with others (nations), the construction of national identity or consensus involves the evasion of internal anxiety and controversy (Morley and Robins, 1995).

\section{Mourning Pim}

Dayan and Katz (1993, p. 9) distinguish between media events and news events. Great news events, such as the murder of Fortuyn, "speak of accidents, of disruption". But the pre-planned live broadcast of Pim Fortuyn's funeral service and the funeral procession fits their definition of a media event: a great ceremony "to celebrate order and its restoration". We are interested in the relationship between news events and media events. It is not unusual that death shatters social life, and creates a need to restore it through rituals and other means. As Walter (1999, p. xiii) notes in his book about mourning Diana, death "provides a natural experiment in how a society constructs order in the face of disorder and anomie". Unexpected events can be seen to offer this kind of "natural experiment" for the news media too because they reveal the ideological scripts, conventions and practices of journalists at work. Often a dramatic news event-such as Anna Lindh's murder in Sweden or JFK's in the United States - can be 
turned almost naturally into an order-restoring media event; this was much more problematic with such an ambiguous figure as Pim Fortuyn, even if the need to restore order was felt to be urgent.

Interestingly, the editor of the public NOS Journaal claims that journalists had only little idea of what they were doing in the days immediately following Fortuyn's death. Instead of asking the "Yes, but..."-questions and providing context and explanation, they were carried along by the event, unable to do more than just register, and it took a week before they had come to grips with the situation and felt able to resume their normal journalistic functions. ${ }^{4}$ What we are interested in here could be summed up as, what are journalists doing when they don't know what they are doing?

\section{"That Such a Thing Could Happen in the Netherlands"}

The murder of a politician, no matter how controversial, in the midst of the national election campaign, has particular symbolic implications, as well as political and social impacts. Therefore, it is not surprising that the murders of politicians in office such as Palme and Kennedy have been portrayed as historical turning points (e.g. Turnock, 2000, p. 33). This narrative device, connecting all sort of tragic events throughout the time, was widely used in the Dutch news media. Journalists who look for stories that symbolize change and turning points marked the murder of Fortuyn as a moment when the peaceful and tolerant Netherlands "lost its innocence". As Dayan and Katz (1993) write, media events are also about recording events in collective memory and revising collective memory. Giving a historical frame, the Palme and Kennedy murders were associated with the Fortuyn murder, as were the public reactions of the Dutch people with the reactions of the mourners of Diana. Reminding the audience about the fact that Fortuyn's murder was the first political assassination in the Netherlands since the 17th century served to highlight the significance of the event.

Stressing that the murder of Fortuyn was completely alien to Dutch political culture,
Dutch political history and commonly held Dutch democratic values, the media and authorities also created a binding element in a dramatic event. "What no one thought would be possible in the Netherlands, did happen after all", is the sentence with which the NOS Journaal opened on 6 May, the night of the murder. Comments like this presuppose a shared terrain of Dutchness into which this political murder does not fit. That message was repeated over and over again, and it was also expressed in many of the street interviews, such as with a man in the NOS Journaal (10 May): "That such a thing could happen in the Netherlands. I would never have expected that." Or with the crying elderly man, who had just left the catholic cathedral in Rotterdam, where thousands of people were queuing for hours to pay their respects before Fortuyn's open white coffin: "It feels like losing a child. That this is possible in the Netherlands..."

The approach of the assassination as a turning point includes an analysis of change from - in this case - an idealized past to a troublesome present and an uncertain future. In his introductory statement (NOS Journaal, 7 May), the news presenter suggested that the assault on Fortuyn was made possible by "a hardening society". In the same news broadcast ordinary people interviewed offer similar personal views about what has happened in the Netherlands. A middle-aged woman comments that "The Netherlands have changed due to negative influences" but she does not identify what those influences are. Another interviewee, an elderly woman accompanied by a younger woman, connects the unwelcome change to free speech: "You just cannot say what you want to say anymore ... I used to be a ticket collector on the buses and if I did not like how things were going, I would say to someone who misbehaved: 'Next stop you get off'."

\section{"I Feel Completely Devastated"}

In the days following the death of Pim Fortuyn television news focused on people who were visibly emotionally affected, people like the weeping woman cited in the title in the NOS Journaal of the day of the funeral (10 May). 
A wide range of expressions of emotions that were displayed was readily accepted as part of a normal or even expected mourning repertoire. Next to the more conventional condolence register, these included silent marches, candles, flowers, dolls, letters, poems, and drawings. At the memorial site in the Mediapark, where he had been assassinated, people even laid down his favourite cigars and attached the striped neckties that he used to wear to the gate. There is not too much difference between the images on Dutch public and private broadcast news. Ordinary people interviewed in the streets or on other locations, women and men alike, are often in complete shock, tears running down their cheek, and comforting each other.

As Hartley (1995; also Fiske, 1987) has noted, in television news only ordinary people are asked about their feelings. Ordinary people's stories serve the function of positioning the viewer in a more direct relationship with the events and those involved and thus add force to the emotional intensity of the event (Langer, 1998 , p. 87). Information that matters - knowledge, standpoints - comes from experts and institutional voices. Experts and politicians are normally expected to be rational, but in the case of dramatic events they are requested to show emotion like everybody else, thus helping to create an impression of a generally felt loss and of shared grief. Other ways of differentiating between voices in televisual texts may be reversed as well, and so for a few days the normally subordinate views of ordinary people who in terms of traditional news values are generally excluded from news, may dominate the news coverage of shocking events like natural disasters, crime and accidents, and may be treated as the official point of view, or the nation's point of view (see Couldry, 1999).

Despite the large amount of politicians in the main news broadcasts on RTL4 and NOS, they are easily outnumbered by ordinary people being interviewed in the streets or at the official or unofficial sites of mourning. We are not sure if the range of voices commenting on the situation was much wider than under normal circumstances. It was certainly different. On one hand, more extremist and racist and angrier sounds were to be heard than under normal conditions, though more in the live reports than on the main news of NOS and RTL. However, it was not these angry voices on which the news focused. In most cases ordinary people were asked how they felt, and most of them demonstrated deep personal involvement with the deceased or the events surrounding his death, and cameras zoomed in on expressions of grief, faces of women and men with tears running, emotional texts, or a doll left behind at a gate. These are a few examples:

Woman (RTL Nieuws, 7 May): "This man wanted to help us. I have no word for this."

Woman (RTL Nieuws, 8 May): "Goodbye, dear Pim. Thank you for everything. I am going to miss you." Woman (NOS Journaal, 9 May): "This shouldn't have been. He was a man with a twinkle in his eye, and it is no longer there."

Boy (NOS Journaal, 10 May): "I did not look at how he looked. I looked deep into his eyes, and I saw love, honesty and trustworthiness."

What is interesting is that despite the manifestly political nature of the murder these "vox pops" were almost exclusively apolitical. Citizens expressed an emotional response, or complaints such as "we are going down, the whole of Europe is going down" (woman in RTL Nieuws, 7 May), but they did not, on the whole, discuss the political element of the event, or its potential political outcome. Neither did they offer explicit political opinions on what should be done to prevent the country going down. When politics were mentioned, it was most likely connected to Fortuyn's personality or to the feeling of grief. For instance, in public TV news (NOS Journaal, 7 May) "hundreds of people" were shown waiting in line to sign a condolence register. Then came a close-up of two teenage girls, one of whom was crying silently, a tear running down her cheek. The girl who wasn't crying was interviewed: "He was such a charismatic man who had a good sense of humour and he spoke a language which we could understand. Thanks to him, young people got interested in politics again. And now, well,... I don't know. I really don't know." 


\section{"The Netherlands is in Mourning"}

Television went to great lengths to demonstrate the universality of the shock and the unity of the nation, which was not an easy task given the controversial nature of Fortuyn and his political ideas, and the heated discussions in and outside the media of the previous months. The images of mourning people in the news illustrate the intensity of grief, in addition the mourning of Fortuyn is given a nation-wide character by such signs as the obituaries narrating Fortuyn's political career, attendance of the funeral service by the cabinet, party leaders and other members of parliament, live reports by the national media, providing information to their viewers on how to participate in mourning, such as the locations and hours of registers where people can offer their sympathy and condolences.

RTL4 ("The Netherlands is in Mourning", 7 May) stressed the national character of mourning and the funeral somewhat more than NOS, for instance by providing detailed information about how viewers might attend the funeral service, and about the time-schedule and route of the funeral procession, but NOS also showed a map with places where silent processions would be held. In doing so they created the conditions for new news events, consciously or not. If the mourning was not described as national, it was at least depicted as massive, and having un-Dutch proportions and style. As the presenter of RTL Nieuws stated in her opening sentences of the news of 10 May: "The farewell to Pim Fortuyn has turned into an event, such as the Netherlands has never seen before. Many people crying, continuous applause all along the route, spontaneous singing, and people who try to touch the hearse."

Authorities and media may have wanted to downplay the controversial character of the occasion, but the problem was not evaded completely. The NOS Journaal presenter on 10 May said that Fortuyn's funeral had "the scale and the style" of a national funeral, but he stopped short of calling it a national event. Similarly, presenters and correspondents in other news broadcasts often, though not always, showed some hesitation or restraint in using such a term to describe the situation, as the following examples show:

Presenter (NOS Journaal, 7 May): "The Netherlands seems to be immersed in collective mourning."

Presenter (NOS Journaal, 10 May): "When you see all these thousands, can you say that there was consensus in mourning?"

Correspondent: "Yes you could say that ... although there are also people who have little understanding for this loud, collective mourning."

An RTL Nieuws reporter spoke on 10 May of "Diana-like scenes" and another one on the same day of "un-Netherlandish situations", when people wanted to touch the hearse carrying the corpse of Fortuyn. On the other hand, presenters and reporters did not show much surprise at other expressions of mourning that had not been current before in the Netherlands either, such as the throwing of petals and flowers, a familiar scene from Diana's funeral, or lying in state that is almost unprecedented in the Netherlands.

Reporters had more difficulty in interpreting the more politically tainted expressions of emotion or of political protest, such as the chanting and whistling by supporters of Feyenoord football club of Rotterdam, the angry slogans against the government shouted by right-wing activists, or the posters demanding the death of the prime minister. They were not disregarded but interestingly they seem to have been accepted as belonging to a wide diversity of sometimes strange but nevertheless legitimate expressions of grief, now that mourning had been defined as nationwide. For instance, an NOS Journaal item (9 May) about people paying homage to Fortuyn included footage of people shouting "Pim Fortuyn", clapping their hands or lifting their fists. The camera zoomed in on a young man who shouted that the Purple cabinet must be punished and that everybody should vote for Fortuyn. The reporter commented on this footage by saying that the "collective grief" seems to lead to some rather frightening reactions. 
That the news media was engaged in negotiating between appropriate grieving and mass hysteria, which is typically feared by political and cultural elite, was made rather explicitly in RTL News (10 May), where the reporter on location was specifically asked to give his personal assessment about special forms of mourning:

Presenter: "Are you impressed?" [about the loud slogans and chanting from the crowds]

Correspondent: "Yes Jeroen, I guess I am. Some people found that improper ... but not many. And I did not really find it improper either."

On the night of 8 May, when Feyenoord football club had to play their UEFA Cup final, the NOS correspondent in Rotterdam also made an effort to reconcile the exuberance of football supporters in front of the Rotterdam town hall, with the grief of other people who where laying down flowers for Fortuyn there. Although he acknowledged a "symbolic divide", he added, referring to the dancing and singing supporters: "But don't forget that these are actually the same people who have paid their respects earlier today" (NOS Journaal, 8 May). A Feyenoord fan further confirmed the connection between football partying and mourning for Pim: "I hope Feyenoord wins this game for Pim Fortuyn." Also the RTL correspondent reported that they were actually singing about Pim Fortuyn (RTL Nieuws, 8 May).

How television news gave precedence to community over disunity can also be illustrated by a sequence of shots in the NOS Journaal of 7 May. First we see images of people bringing flowers to the square in front of the Houses of Parliament in The Hague, while in the background burnt-out car wrecks are being towed away by cranes, and a voice-over explains that these are the remains of riots of the night before. Then the camera turns again to the images of flowers, candles, poems being laid down and finally to images of Prime Minister Wim Kok, who is making a statement in the House: "The Dutch can take a lot, and this is a good signal to everybody that our democracy is still functioning..."

\section{"Is Anything Known About... Skin Colour?"}

The main concern of Dutch television journalists seems to have been that the disunity in the nation would take an ethnic turn. Public television news in particular, but commercial broadcasting as well, made an effort to try to take away any impression that Fortuyn's death might have anything to do with the ethnic factor, obviously considered to be the most disruptive and harmful to national unity. "Did anyone get a glimpse of the perpetrator? Is anything known about-[pause]-say, skin colour?", was one of the first questions asked by the NOS news presenter on the night of Fortuyn's murder. A little later the NOS Journaal hastened to announce, with obvious relief, that the arrested suspect was a white male. Until that time the mentioning of ethnic background had been considered highly irregular. ${ }^{5}$ Laroes of NOS News described the situation on the night of the murder as follows:

I remember that we, at that moment at 8 o'clock, as editor of the day, did something that we had not done before: told the presenter that he should say that the man who had then been apprehended, that it concerned a white Dutch male. I found it important to say that, because what everyone first expected no doubt was that the man concerned would be an immigrant. If it had been an immigrant the situation would have been even more chaotic and aggressive, I think. ${ }^{6}$

It is noteworthy that the news about the suspect's skin colour and nationality came as a relief. Noteworthy, because it shows what kind of murderer the journalists themselves had expected. And also because a coloured, especially a Muslim, suspect was supposed to have been problematic. Even after the identity of the suspect had been disclosed, the news continued to operate from this perspective, working to contain the potential for ethnic or religious conflict. ${ }^{7}$

Fortuyn had a mixed following and his electoral list contained several representatives of ethnic minorities, but because of his outspoken anti-immigration, anti-Muslim, and antimulticultural society political programme his enemies were automatically expected from that side. It is therefore interesting to see that Dutch television news, both public and commercial, often zoomed in on people of colour in the street 
processions, funeral crowds, and gave more than ample room in lay interviews and "expert" interviews to representatives of ethnic minorities: NOS Journaal (10 May), for instance, interviewed Imam Abdullah Haselhoef on the day of the funeral. The number of representatives of ethnic minorities is larger than could have been expected if one compares it with the composition of the mourning or protesting crowds that could be seen on television during those days.

Furthermore, a substantial number of people, who could be held to represent the voice of ethnic minorities in Dutch society, or who were put by television in that role, testified how much they regretted the political murder and the death of Fortuyn. Two examples:

Mohamed Sini of the Islam and Citizenship Society (NOS Journaal, 7 May): "This is a tremendous shock for the whole of Dutch society, and also for us as Muslims."

Ahmed Aboutaleb, head of Forum, an organization representing ethnic minority interests (NOS Journaal, 7 May): "The Netherlands has 16 million inhabitants. The 16 million are shocked. The 16 million are a nation. You cannot take 1.7 million out."

On the same day, a voice-over at RTL Nieuws (7 May), accompanying pictures of people signing the register at Fortuyn's house, declared that migrant organizations such as Turkish Milli Görüs would pay their respects later that day. The numerous street interviews contained no real critical remarks about Fortuyn and his policies or anything else that might disturb the consensus in mourning. In the 8 o'clock NOS Journaal of 10 May, the day of his funeral, the only interviewees expressing serious doubts were both white and interviewed at some distance from the crowds.

\section{"Which Role the Media Might Have Played?"}

In the aftermath of his death Fortuyn's party lawyers accused the Dutch government of having failed to protect Fortuyn adequately, and filed charges against several Dutch politicians, journalists, media columnists and media, for having contributed to a climate in which he could have been murdered. Fortuyn himself, in a talk show interview shortly before his death, repeated on the news after his death (RTL4 Nieuws Extra, 6 May), had claimed that the government that had "demonized" him, would have to be held responsible, if something ever happened to him. The public outcry at his death and the results of the general elections suggest that many may have shared this view.

One important reason for the large number of ordinary people as "lay experts" may be that first Fortuyn's electoral success and now his death seemed to have proved that the media had failed to register the massive discontent below the quiet waters of Dutch multicultural society. During the first days after his death reporters met with clear animosity from the crowds. Although RTL had had a less troublesome relationship with Fortuyn than the public broadcaster, the public seemed to blame the media in general for having maltreated Fortuyn, echoing Fortuyn's and his group's view during the election campaign. Especially public television news tried to convey the message that it had dealt fairly with all political parties, including Fortuyn's.

On the evening of his murder the NOS news presenter without any immediate reason asked the programme's political correspondent about the media's potential role in the murder: "Do we know which role the media might have played?" The Hague correspondent answered that he did not know, but "wouldn't say there is a connection". The next day (NOS Journaal, 7 May) the conversation turned to the neutrality of public television news itself. The correspondent, Job Frieszo, had been accused of tendentious reporting, when he had held up in front of the camera the party programme of an extremeright party while talking about Pim Fortuyn's standpoints: ${ }^{8}$

Presenter (NOS Journaal, 7 May): "Herben [spokesman of Fortuyn's party] has criticized the media."

Correspondent: "Fortuyn attacked the establishment, including the established media ... Fortuyn was quite different from other politicians and therefore automatically newsworthy. Now and then he may have been put down as an extremist, but the media have 
dealt with him mostly in a business-like sort of way."

\section{Discussion}

It has been noted by several authors that the pressures to claim that society comes together are intensifying as the material basis of shared experience is becoming more precarious (e.g. Bauman, 2001a, 2001b). Media events are usually seen as occasions of affirmation of the national community, which might otherwise only have an ambiguous social existence. However, like Couldry (2003), we see media events as much as constructions as expressions of togetherness. For a dramatic news event to become a national and media event with a potential for feeling community, more is needed than a nationwide live televised occasion breaking through normal broadcast schedules. On the other hand, even unlikely candidates for the position of a media event can be made to look as such by de-emphasizing their disruptive potential, by broadening the definition of legitimate ritual, by de-politicizing signs of opposition, by focusing on emotion, and giving preferential treatment to the voices of unity. As we have shown, the news forged a sense of emotional unity by the representation of mourning and rearticulated political outrage as personal anxiety by focusing on questions like how people felt about the murder. The reason may be political, an urgent need to try to re-establish a sense of togetherness, where none is available.

The need to define Fortuyn's death as a national event seems to have been shared by the media, mourning citizens and the government, but for different reasons. Television's efforts to construct or reconstruct national consensus seem to have been led by its interpretation of the issue at stake in terms of the cherished Dutch values of the multicultural society. Although media are at the centre of the construction of a national event and Dutch television news played an active part in framing the murder of Fortuyn in this particular way, their role may still have been more its conductor than its author. Larger segments of the general public, as well as the government, may exercise pressure for a controversial event to be handled in a particular manner, and this concerns also its coverage by the media (cf. Dayan, 2001). To see his death and funeral accepted as a national tragedy gave some satisfaction to the dissatisfied in Dutch society.

The construction of a feeling community through the rhetoric of unity and representations of mourning was, however, a difficult task for the Dutch media. Media events may provide opportunities for underlying conflicts to be expressed and negotiated as they are "points of maximum turbulence" and "sites of popular engagement and involvement" (Fiske, 1994). This opportunity was not taken up by the media, at least not at that time. The political protest at Fortuyn's death was rendered harmless by re-defining it as belonging to a range of reasonable expressions of national mourning. Many acts, which could have been understood as acts of protest and anger, such as the applause, the letters that were attached to the gate of Mediapark, were presented as expressions of grief. The fact that the news of his death may actually have been greeted with a sense of relief or indifference in some circles remained unacknowledged, perhaps not because the media neglected these feelings on purpose, but because they were not expressed openly.

We also argue that the question was not of the defence of social values alone but of the media's authority and social status. Eventually the death of Fortuyn led Dutch public TV news to critically reappraise its policies and procedures. The unexpected anger and discontent mobilized by Fortuyn seemed to confirm that the media in general, and public television in particular, had lost touch with large strata of Dutch society. Public television news set out to deal with the more problematic sides of multi-ethnic Dutch society as well with a new motto Staat en Straat, State and Street. News was to become more representative, more relevant and more accessible (NOS Journaal, 2002).

Given the controversy surrounding Fortuyn, his death and funeral cannot be termed a national event in the same way as those of Anna Lindh, Olof Palme or even Princess Diana. Nevertheless, his death and funeral came to be raised to the status of national events by 
extensive live coverage both on public and private television. Mourning his death was sanctioned as national mourning if only by the presence of government ministers and members of parliament at his funeral service (even if they entered by the backdoor). The political murder itself had a traumatic impact and came as a shock, but Fortuyn alive had been a shock to dominant political values in Dutch society, as well. Much like Princess Diana had functioned vis-à-vis the royal establishment of the Windsors in Britain (e.g. McGuigan, 2000), he had repre- sented the protest of disgruntled people against established politics in the Netherlands. His death also had a disruptive and divisive potential. The construction of Fortuyn's death and funeral as national events bears the marks of the unacknowledged rift between the discontent below the surface of Dutch society and the official ideology of the free, open and tolerant multicultural society. Defining the tragedy as national can be perceived as a way of reducing tension and forging a sense of emotional unity; that is, constructing a nationwide feeling community.

\section{Notes}

1 Theo van Gogh was shot and stabbed to death in broad daylight on 2 November 2004. The death of this outspoken filmmaker seems to be directly connected to a short film Submission he produced together with Member of Parliament Ayaan Hirsi Ali, in which the treatment of women in Islam and in the Koran was severely criticized. The noisy memorial service was announced by Amsterdam Mayor Job Cohen a few hours after the murder, when it became clear that the murder was connected to Van Gogh's controversial opinions (see "Thousands Make a Racket at Van Gogh Rally", Expatica, 3 November 2004).

2 SBS has been more successful with its late evening Hart van Nederland, a news programme focusing on regional news and human interest.

3 Interview with Hans Laroes, 25 June 2004

4 Interview with Hans Laroes, 25 June 2004.

5 Interview with Hans Laroes, 25 June 2004. A similar attitude was displayed early on the day of the assassination of newspaper columnist and filmmaker Theo van Gogh. During extra television news broadcasts his suspected murderer was described as dressed as someone with an Islamic background or someone who wanted to appear as such.

6 Interview with Hans Laroes, 25 June 2004.

7 The TV news did pay attention to the suspected murderer's background and his previous activities in environment protection and animal rights groups, but that matter was not treated as potentially disruptive.

8 Nico Haasbroek, the executive producer of the NOS Journaal, who had openly criticized his correspondent in another TV programme, resigned or was forced to resign.

\section{References}

Aldridge, Meryl (2001) “Confessional Culture, Masculinity and Emotional Work”, Journalism 28(1), pp. 91-108.

Anderson, B. (1991) Imagined Communities: reflections on the origin and spread of nationalism, London: Routledge.

Bauman, Zygmunt (2001a) Community: seeking safety in an insecure world, Cambridge: Polity Press.

Bauman, Zygmunt (2001b) The Individualized Society, Cambridge: Polity Press.

Berezin, Mabel (2002) "Secure States: towards a political sociology of emotion", in: Jack Barbalet (Ed.), Emotions and Sociology, Oxford: Blackwell.

Brants, Kees and de Bens, Els (2000) "The Status of TV Broadcasting in Europe", in: Jan Wieten, Graham Murdock and Peter Dahlgren (Eds), Television Across Europe. A comparative introduction, London: Sage, pp. 7-22.

Cardiff, David and Scannell, Paddy (1987) "Broadcasting and National Unity", in: James Curran, Anthony Smith and Pauline Wingate (Eds), Impacts and Influences: essays on media power in the twentieth century, London: Methuen.

Carey, James W. (1989) Communication as Culture: essays on media and society, Winchester, MA: Unwin Hyman.

Cloud, Dana L. (1998) Control and Consolation in American Culture and Politics: rhetoric of therapy, Thousand Oaks, CA: Sage.

Couldry, Nick (1999) "Remembering Diana: the geography of celebrity and the politics of lack", New Formations 36, pp. 77-91.

Couldry, Nick (2003) Media Rituals. A critical approach, London: Routledge.

Dayan, Daniel (2001) "The Peculiar Public of Television", Media, Culture E Society 23(6), pp. 743-65.

Dayan, Daniel and Katz, Elihu (1993) Media Events. The live broadcasting of history, Cambridge, MA and London: Harvard University Press.

De Rivera, Joseph (1992) “Emotional Climate: social structure and emotional dynamics”, International Review of Studies on Emotion 2, pp. 197-218.

Fiske, John (1987) Media Culture, London: Methuen.

Fiske, John (1994) Media Matters: everyday culture and political change, Minneapolis: University of Minnesota Press.

Furedi, Frank (2004) Therapy Culture: cultivating vulnerability in an uncertain age, London: Routledge. 
Goodwin, Jeff, Jasper, James M. and Polletta, Francesca (Eds) (2001) Passionate Politics: emotions and social movement. Chicago: The University of Chicago Press.

Harrison, Jackie (2000) Terrestrial TV News in Britain, Manchester and New York: Manchester University Press.

Hartley, John (1995) Understanding News, London and New York: Routledge.

Kitch, Carolyn (2000) "'A News of Feeling as Well as Fact'. Mourning and memorial in American newsmagazines", Journalism 1(2), pp. 171-95.

Kitch, Carolyn (2003) "'Mourning in America': ritual, redemption, and recovery in news narrative after September 11", Journalism Studies 4(2), pp. 213-24.

Kitzinger, Jenny (1998) "Image", Screen 39(1), pp. 73-9.

Langer, John (1998) Tabloid Television. Popular journalism and the "other news", London: Routledge.

Linenthal, Edward T. (2001) The Unfinished Bombing: Oklahoma City in American memory, New York: Oxford University Press.

Lupton, Deborah (1998) The Emotional Self. A sociocultural exploration, London: Sage.

Marcus, George E. (2002) The Sentimental Citizen: emotion in democratic politics, University Park, PA: Penn State University Press.

McGuigan, Jim (2000) "British Identity and 'the People's Princess"', The Sociological Review 1(48), pp. 1-18.

Mestrovic, Stjepan (1997) Postemotional Society, London: Sage.

Morley, David and Robins, Kevin (1995) Spaces of Identity: global media, electronic landscapes, and cultural boundaries, London and New York: Routledge.

NOS Journaal (2002) Ten Aanval, http://www.nos.nl/journaal/indiscussie/beleid/index.html, accessed 26 July 2004.

Örnebring, Henrik (2004) "Revisiting the Coronation. A critical perspective on the coronation of Queen Elizabeth II in 1953", Nordicom Review 1/2, pp. 175-95.

Pantti, Mervi (2005) "Masculine Tears, Feminine Tears - and Crocodile Tears: mourning Olof Palme and Anna Lindh in Finnish newspapers", Journalism: theory, practice and criticism 6(3), pp. 357-77.

Shilling, Chris (2002) "The Two Traditions in the Sociology of Emotions", in: Jack Barbalet (Ed.), Sociology and Emotions, Oxford: Blackwell.

Syvertsen, Trine (1992) Public Television in Transition, Oslo: KULT.

Turnock, Robert (2000) Interpreting Diana. Television audiences and the death of a princess, London: British Film Institute.

Walter, Tony (1991) "The Mourning After Hillsborough", Sociological Review 39(3), pp. 599-625.

Walter, Tony (Ed.) (1999) The Mourning for Diana, Oxford: Berg.

Walter, Tony, Littlewood, Jane and Pickering, Michael (1995) "Death in the News: the public invigilation of private emotion", Sociology 29(4), pp. 579-96.

Zoonen, L. van (2002) Media, Cultuur en Burgerschap, Amsterdam: Aksant. 